Research Report No. 26/2009

\title{
Brazilian Legal Education: Curricular Reform that Goes Further Without Going Beyond
}

Roberto Fragale Filho

Follow this and additional works at: http:/ / digitalcommons.osgoode.yorku.ca/clpe

\section{Recommended Citation}

Filho, Roberto Fragale, "Brazilian Legal Education: Curricular Reform that Goes Further Without Going Beyond" (2009). Comparative Research in Law \& Political Economy. Research Paper No. 26/2009.

http://digitalcommons.osgoode.yorku.ca/clpe/139 


\section{Roberto Fragale Filho}

\section{Brazilian Legal Education: Curricular Reform that Goes Further without Going Beyond}

EDITORS: Peer Zumbansen (Osgoode Hall Law School, Toronto, Director, Comparative Research in Law and Political Economy, York University), John W. Cioffi (University of California at Riverside), Nassim Nasser (Osgoode Hall Law School, Toronto, Production Editor)

Also available at: http://www.germanlawjournal.com 



\section{German Law Journal}

Brazilian Legal Education: Curricular Reform that Goes Further without Going Beyond Roberto Fragale Filho

10 German Law Journal 751 (2009), available at:

http://www.germanlawjournal.com/article.php?id=1148

This article was originally published in Volume 10, Number 7 of the German Law Journal as part of the journal's $10^{\text {th }}$ anniversary symposium on "Transnationalizing Legal Education" edited by Nadia Chiesa, Adam de Luca, and Bernadette Maheandiran. 
CLPE Research Paper 26/2009

Vol. 05 No. 04(2009)

Roberto Fragale Filho

\title{
Brazilian Legal Education: CurRicular ReForm that Goes Further WITHOUT GOING BEYOND
}

\begin{abstract}
Brazilian legal education is engaged since 1994 in a long and inconclusive process of curriculum reform in which the Brazilian Bar Association (Ordem dos Advogados do Brasil) has been one of its greatest players. The transformations undertaken in legal education in the last two decades, were buoyed by three things: (a) the redemocratization of the country, completed in 1988 with the promulgation of the new Constitution, (b) the expansion of higher education, which resulted in a amount of more than half of a million law students, and (c) the protection of interests of the lawyers' corporation, even though it has been done under the argument of a genuine defense of a minimum level of quality for the Brazilian legal education. Interestingly, all this reform process is done without any trace of dialogue with the Bologna process and rarely integrating the challenges of a legal practice increasingly internationalized. This article proposes a critical review of the incomplete process of legal education reform, seeking to understand how, despite its original purposes, it has been imprisoned on the one hand, by the corporate share of the Brazilian Bar Association and on the other hand, by the reproduction of old practices in the teaching of Brazilian law. Finally, between the reproduction of the past and the uncertainty of the future, Brazilian legal education is facing a broad challenge that goes beyond the definition of its curriculum structure. In short, rethink the foundations of its access, the parameters of its offer and the importance of its social impact is undoubtedly a necessity to adequately speculate about the future of Brazilian legal education.
\end{abstract}

Keywords: Legal education, Curricular changes, Brazilian Legal Education

JEL classification: K10, K40

Roberto Fragale Filho

Universidade Federal Fluminense and Fundação Getúlio Vargas,

Rio de Janeiro, Brazil.

Email: fragale@alternex.com.br 



\title{
Special ISSUE: Transnationalizing Legal Education
}

\section{Brazilian Legal Education: Curricular Reform that Goes Further without Going Beyond}

\author{
By Roberto Fragale Filho*
}

The celebration of 180 years of legal education in Brazil, held in August 2007, was marked by strong criticism of the Ordem dos Advogados do Brasil (Brazilian Bar Association) and the higher education expansion policy which was undertaken in the late 1990s, establishing more than a thousand law schools in the country. ${ }^{1}$ The escolas de enganação (schools of illusion), ${ }^{2}$ created mainly during the last decade, would have increased the numbers in the professional college, which currently has around 600,000 lawyers, to approximately two and a half million, if it were not for the professional filter of the Bar Exam. In other words, the proliferation of mass legal courses in Brazil would have enabled the emergence of educational merchants, ${ }^{3}$ specializing in the sale of an illusion of social elevation and professional success, which, thanks to the control of entry into the professional corporation, did not happen.

In addition to the firm criticism and the symbolism around the time of its disclosure, the celebration of the origins of legal education also coincided with the introduction of reforms in higher education in Brazil, and provided the restoration of a partnership between the Ministério da Educação (Ministry of Education) and the Brazilian Bar Association. This partnership started the long process of control and evaluation in many law schools. In the days following the celebration of 180 years of legal education in Brazil, the Bar denounced a set of legal courses based on their results on the Bar Exam and the Exame Nacional de Desempenho de Estudantes (National Exam of Students' Performance). This was proof of the low quality of the courses, and by consequence, required the energetic intervention of the Ministry. A list of 89 legal courses was established and served to justify the results. The Ministry further specified the measures and arrangements which would be taken to overcome the deficiencies in the legal programming. Although this process has not yet

\footnotetext{
* Universidade Federal Fluminense and Fundação Getúlio Vargas, Rio de Janeiro, Brazil. Email: fragale@alternex.com.br

${ }^{1}$ See the speech of Brazilian Bar Association President, Cezar Britto at http://www.oab.org.br/noticia.asp? id=10699, last accessed 20 February 2009.

${ }^{2}$ See http://www.oab.org.br/noticia.asp?id=10772, last accessed 20 February 2009.

${ }^{3}$ Eliane Botelho Junqueira, FACUldades de DiReito ou FÁbricAS de ILUSÕEs? (1999).

${ }^{4}$ The list is available at http://portal.mec.gov.br/arquivos/pdf/tabela_2.pdf, last accessed 19 February 2009.
} 
been concluded, it has allowed the Bar to rise to the preeminent position that it enjoyed in the curriculum reform of 1994, when its proposals were the basis for a legal education reform.

As a matter of fact, the transformations undertaken in Brazilian legal education in the last two decades were buoyed by three things: (a) the redemocratization of the country, completed in 1988 with the promulgation of the new Constitution, (b) the expansion of higher education, which resulted in the enrollment of more than half a million law students, and (c) the protection of interests of the lawyers' corporation, even though it has been done under the banner of a genuine defense of a minimum level of quality for the Brazilian legal education. Through this process, the Brazilian Bar Association went from a major actor in the curriculum reform of 1994 to a marginalized participant in expansion of higher education and, finally to a partner in the recent adjustments made in the educational system. Such a trajectory is extremely significant and allows us to understand the actual scenario of Brazilian legal education. Within this process, one can hardly find any trace of dialogue with the Bologna process. Further, the integration of new technologies and engagement with the challenges of an increasingly internationalized legal practice are extremely rare. This article proposes a critical review of the incomplete process of legal education reform in three different parts: (a) the expansion, (b) the curriculum, and (c) the control over the profession.

\section{A. The expansion}

In 1827, just five years after its independence from Portugal, Brazil created its first two law schools in São Paulo and Olinda (lately transferred to Recife, in the State of Pernambuco), where the political and administrative imperial elite was formed. ${ }^{5}$ Four new schools were created in the first decade of the Republic, which was proclaimed in 1889. These schools were established mainly as a strategic action of the new government, which needed new institutions to oppose the two old imperial schools, still strongly marked by a monarchist political vision. ${ }^{6}$ By 1927, when Brazilian legal education celebrated its hundred year anniversary, the country had only 13 law schools. When the military government took over in 1964, the number of law schools had almost quintupled as it had reached 64. As a strategy for capturing middle class support, the military government launched a wave of higher education expansion and, by 1977, as Brazilian legal education was commemorating one and a half century of existence, the number of law schools had almost doubled. In only thirteen years, the military had created the same number of schools as had been created in

\footnotetext{
${ }^{5}$ Aurélio Wander Bastos, Criação dos cursos JuRídicos no Brasil (1977) and O ensino JuRídico no Brasil (1998); SÉRGIO AdORNo, OS APRENDIZES DO PODER (1988).

${ }^{6}$ Daniel Torres de Cerqueira, $O$ ensino jurídico no Brasil: breve radiografia do setor, 4 ANUÁRIO ABEDI, 87, 95 (2006).
} 
the previous 137 years. But, the expansion went still further and by 1997, the number of law schools had almost tripled again. Ten years later, continuing along this wave of expansion, as Brazilian legal education completed 180 years of existence, the number of law schools exploded and passed the cap of a thousand, as it can be seen in figure I.

Figure I

Evolution of law schools

$1827-2007^{7}$

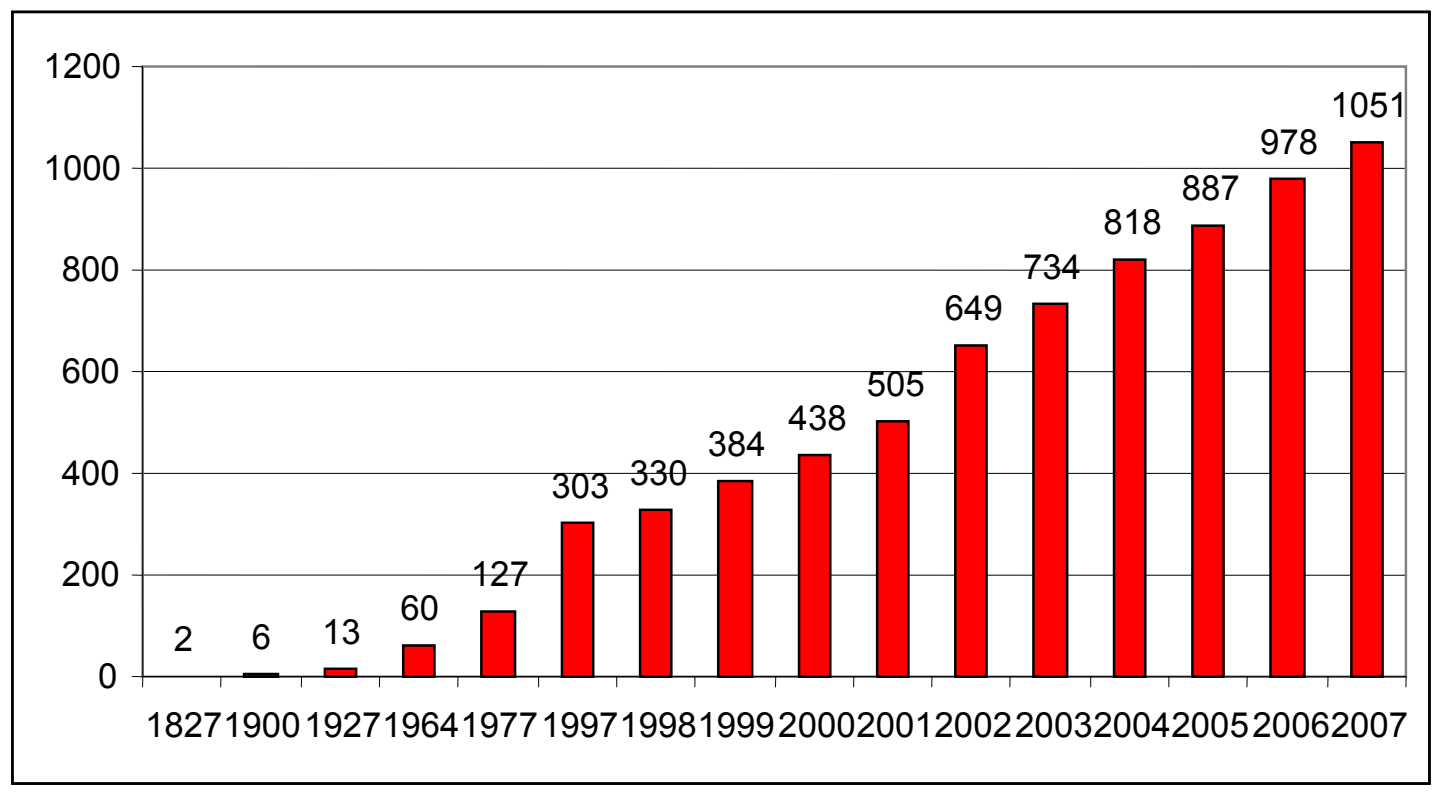

As it can be seen in figure II, this scenario affects a large number of people, as it creates an immense student population. In fact, student population has more than doubled, going from 265,005 to 613,950 over the last ten years. But, the growth pace has considerably slowed since 2004, as the year average expansion of the student body population went from a range between $9 \%-12 \%$ to $4 \%-6 \%$.

\footnotetext{
${ }^{7}$ Data collected from Daniel Torres de Cerqueira, O ensino jurídico no Brasil: breve radiografia do setor, 4 ANUÁRIO ABEDI, 87 (2006) and InStITUTO NACIONAL DE Estudos E PESQUISAS EdUCACIONAIS ANísIO TEIXEIRA, CENSO DA EdUCAÇÃo SUPERIOR 2007, available at http://www.inep.gov.br/superior/censosuperior/sinopse/, last accessed 18 February 2009.
} 
Figure II

Evolution of law students $1997-2007^{8}$

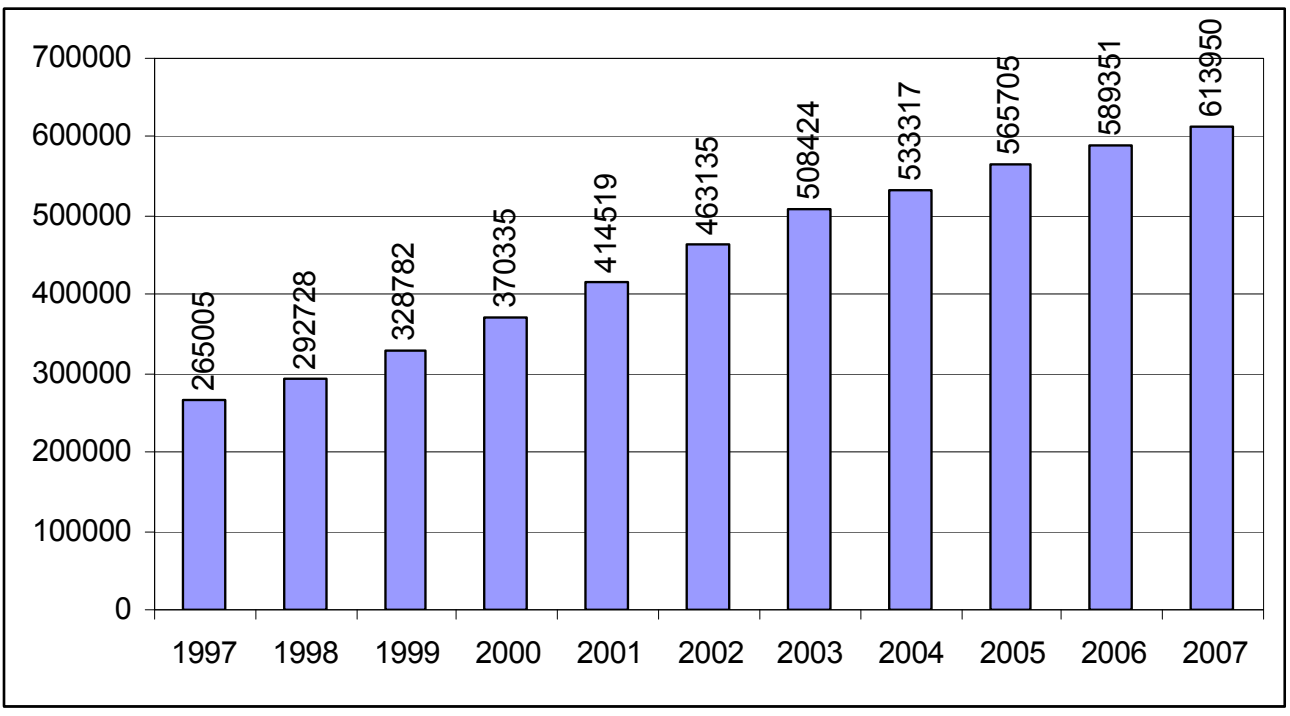

Naturally, criticism of such an expansion arose and the Brazilian Bar Association has been one of the strongest voices, arguing on one side, that it damages the quality of legal education and on other side, the market is already overloaded by lawyers. In other words, the new graduates could hardly find a place in the legal market not only because it is filled to capacity but also because their education was inferior to that of older graduates. However, the major criticism made by the Brazilian Bar was its marginalized role in the expansion. It does not mean that the Brazilian Bar did not have a say in the opening of new law schools as its opinion is required by law. The problem relates to enforcement, owing to the fact that its opinion is still not binding on the Ministry of Education. As a consequence, most of the expansion did not receive the approval of the Bar, as its opinions were against almost all of the proposals for the new schools. ${ }^{9}$

\footnotetext{
${ }^{8}$ Data collected from Instituto Nacional de Estudos e Pesquisas Educacionals Anísio Teixeira, Censo da EducaÇão SUPERIOR 2007, available at http://www.inep.gov.br/superior/censosuperior/sinopse/, last accessed 18 February 2009 .

${ }^{9}$ Between 2001 and 2003 the Ministry of Education authorized 222 new legal courses, of which only 18 had received the assent of the Brazilian Bar. See http://www.gestaouniversitaria.com.br/index.php/edicoes/9-5/23pressao-da-oab-sobre-o-mec-comeca-a-surtir-efeito.html, last accessed 19 February 2009.
} 
What was the reason for such disagreement between the Bar and the Ministry of Education? Mainly, the difference is related to the approach to the expansion of higher education. The Ministry of Education was obligated under the National Plan of Education to expand the system in order to change the higher education system from an elite to a mass system and have the ability to offer, until 2010 , higher education to at least $30 \%$ of the population in the 18-24 year age group. Since there was the capacity to offer higher education to only $12 \%$ of that population at the time the Plan was approved in 2000 , the expansion had to be made at a fast pace. On the other hand, although the Bar agreed that the expansion was necessary, it insisted that the expansion did not have to be made at the expense of legal education.

As they had different approaches to the subject, they also established dissimilar rules to examine a proposal for a new course. While the Bar examined the ratio between local population and the number of possible students for every proposed course, the Ministry analyzed every proposal on an abstract basis. In reality, the criteria of social need created such a discrepancy that it was abandoned by the Ministry by the end of the 1990s. Originally, the criteria of social need was linked to the demonstration of the relevance of the proposed course for its area of deployment in terms of deficiencies in the number of higher-level professionals, or other deficiencies from a cultural point of view. But, since the promulgation of the Lei de Diretrizes e Bases da Educação Nacional (Law of guidelines and bases for national education) in $1996^{10}$, the public policy switched from strong state control exercised at the entrance of the system to a relaxation on the initial elements and greater control over the results of this process, particularly through an assessment of courses and educational institutions. However, the Brazilian Bar did not capture this major change and remained attached to the social needs criteria.

Another major change not perceived by the Bar was the importance of universities' autonomy. While the Bar criticism focused on the number of schools, which did grow over the years, as shown in figure I, the major expansion came from schools already established, which using its prerogative, increased the number of students without having to go through the bureaucratic process that required the participation of the Bar. In a brief period of time, the Bar went from a situation where it had little control over the expansion to another one where it had no control at all.

\section{B. The curriculum}

Legal education in Brazil is not based on Langdell's case method. Since its beginnings in the old practices of the University of Coimbra, it mostly reproduces conference lessons in which professors explain the different doctrinal opinions and guide the students in their

${ }^{10}$ Federal Act no 9,394/1996. 
eventual choice of one of them as the most adequate and representative answer for a judicial problem. In the first years, as described by Joaquim Nabuco, study included, "the Ordinances, the rules and definitions of Roman law, the Napoleonic Code, the praxis, the principles of philosophy of law, and the constitutional theories of Benjamin Constant, all under the general inspiration of Bentham. The French commentators of the Civil Code, Criminal law and Roman law were unknown to the students (as well as) the work of Savigny was not yet translated into French." ${ }^{11}$ The law schools very quickly became places that were not about the law, but were an entrance into Brazilian imperial politics.

Although this was not reformed in the early Brazilian Republic, changes came in two different and important moments - the curriculum reform of Francisco Campos (1931) and the inaugural conference of San Tiago Dantas for the law school year of 1955 at the Faculdade Nacional de Direito (National College of Law) ${ }^{12}$ - both emphasized the building of a technical knowledge, the former expressing strong concern for the shaping of a proper legal reasoning and the latter articulating the importance of a professional perspective for the legal studies. Although neither was able to suppress the idea of law schools as stepping stone to the political world, they were extremely important in establishing a transition period in which, by its end, law schools and their curriculum became essentially technical, distanced from the political sphere. This became even clearer after the military took over and introduced the 1972 reforms.

Introduced by Resolution CFE 3/72, the reform transformed the legal course into an intense series of technical subjects, flourished by a few odd hours of Economics and Sociology. In addition, the law student also had to fulfill physical education requirements and two semester courses on Brazilian problems. Extremely focused on legal technicalities, legal studies basically stepped away from the political arena and concentrated on the maneuvering of the law itself. But, by the end of the 1980's, as the redemocratization process was consolidated through the drafting of a new Constitution (1988), criticism around legal studies gained strength and focused on the need of a radical change in order to prepare students for the new political environment.

In fact, dissociated from the Brazilian new socio-economic context, the curriculum established in 1972 was perceived as unable to respond to social changes that were happening in the country during the 1980s. These changes included enormous transformations in the political scenario and the rediscovery of social movements. The eighties, a long transition period marked by the resurgence of Brazilian politics and the reemergence of collective demands personified in the new unionism, associative and communitarian movements, produced a new socio-economic reality to which legal courses did not provide adequate legal answer. Indeed, the crisis in legal teaching was the product

\footnotetext{
${ }^{11}$ JOAQUIM NABUCO, UM ESTADISTA NO IMPÉRIO 45 (1997).

${ }^{12}$ San Tiago Dantas, Palavras de um Professor (1975).
} 
of a combination of three different problems: the inadequacy of social and vocational training offered at law schools, fewer job opportunities and the loss of professional legitimacy.

Largely stripped of its political purpose, the legal course work offered mainly technical training which, divorced from the socio-economic transformation, did not respond to social demands, or provide access to the labor market. Moreover, in addition to insufficient training, entry into the job market was still hampered by the irregular distribution of geospatial supply and demand, concentrated in large urban centers, leading to advocacy's proletarization. ${ }^{13}$ If in the previous educational arrangement a higher education diploma was already questioned in its capacity to provide for a future job, with a changing economic environment, it stood for an education without social legitimacy, which did not consider the questions of democracy and access to justice, with little (or no) dialogue with other domains of knowledge.

The Brazilian Bar was a major actor in this changing process as it published a series of studies in the first half of the 1990's, establishing a diagnosis of Brazilian legal studies, ${ }^{14}$ proposing new subjects for the curriculum and new methodological strategies for the classroom ${ }^{15}$ and explaining the contents of the curriculum reform approved in December 1994. ${ }^{16}$ Even though the reform did not introduce major changes to the curriculum in a professional content, it produced a major change to the fundamental subjects as it proposed an opening of the course to other areas such as Philosophy and Political Science. Such a demand for an interdisciplinary approach was expressed through a questionnaire conceived by the Legal Studies Commission of the Brazilian Bar and submitted to wellrecognized law teachers in the country. A consensus over the need for foundational reform grew and came to being by the same time that the public policy over the higher education expansion was been established. What no one perceived was that these two movements would soon produce a cross-over and the curriculum reform would be stifled by the massive development of legal studies.

In the wake of this process, the approval of the new Lei de Diretrizes e Bases da Educação Nacional introduced the need for another "new" curriculum for law schools as it demanded new regulations for every higher education course. The Brazilian Bar and legal academia resisted strenuously but finally succumbed and a new curricular reform was enacted by 2004. It preserved most of the 1994 reforms but it amplified the demand for interdisciplinary studies in law schools, as it introduced a required study of Anthropology,

\footnotetext{
${ }^{13}$ Roberto A. R. de Aguiar, A Crise da Advocacia no Brasil: Diagnóstico e Perspectivas (1991).

${ }^{14}$ Ordem dos Advogados do Brasil, Ensino Jurídico: Diagnóstico, Perspectivas e Propostas (1992).

${ }^{15}$ Ordem dos Advogados do Brasil, Ensino Jurídico: ParÂmetros para ElevaÇão de Qualidade e Avaliação (1993).

${ }^{16}$ Ordem dos Advogados do Brasil, Ensino Jurídico: Novas DiRetrizes CurRICULARES (1996).
} 
History and Psychology for law students. As Table I shows, the latest curriculum reforms expanded the need for an interdisciplinary dialogue in the fundamental subjects on the legal curriculum tremendously.

Table I

Fundamental subjects

\begin{tabular}{|l|l|l|l|}
\hline Resolution CFE 3/1972 & \multicolumn{2}{|l|}{ Ordinance MEC 1.886/1994 } & Resolution CNE 9/2004 \\
\hline $\begin{array}{l}\text { Introduction } \\
\text { Study of Law }\end{array}$ & \multicolumn{2}{|l|}{ Introduction to Law } & \\
\hline Economy & Economy & Economy \\
\hline Sociology & Sociology & $\begin{array}{l}\text { Sociology } \\
\text { (general) }\end{array}$ & Sociology \\
\cline { 3 - 4 } & & Sociology of Law & \\
\hline & \multirow{2}{*}{$\begin{array}{l}\text { Philosophy } \\
\text { (general) }\end{array}$} & Philosophy \\
\cline { 3 - 4 } & Philosophy of Law & \\
\cline { 3 - 4 } & Ethics (general) & Ethics \\
\cline { 3 - 4 } & & Professional Ethics & \\
\hline & & Political Science \\
\hline & Political Science and State Theory & Psychology \\
\hline & \multicolumn{2}{|l}{} & History \\
\hline & \multicolumn{2}{|l}{} \\
\hline
\end{tabular}

However, the same expansion was not observed in the professional subjects as it can be seen in Table II. The same contents have been reproduced since the 1972 reform with minor changes, i.e. the two optional contents of 1972 were delimited in 1994 (Fiscal and International Law) and reproduced in 2004 as well the latest reform merged Criminal and Civil Procedure into a general and diffuse Procedural Law. Further, the real changes in the professional disciplines were not introduced as mandatory but as a broad recommendation to incorporate new areas such as Environmental and Consumers Law as well as the study of Human Rights. 
Table II

Professional subjects

\begin{tabular}{|l|l|l|}
\hline Resolution CFE 3/1972 & Ordinance MEC 1.886/1994 & Resolution CNE 9/2004 \\
\hline Constitutional Law & Constitutional Law & Constitutional Law \\
\hline Civil Law & Civil Law & Civil Law \\
\hline Criminal Law & Criminal Law & Criminal Law \\
\hline Commercial Law & Commercial Law & Corporate Law \\
\hline Labor Law & Labor Law & Labor Law \\
\hline Administrative Law & Administrative Law & Administrative Law \\
\hline Civil Procedure Law & Civil Procedure Law & Procedural Law \\
\hline Criminal Procedure Law & Criminal Procedure Law & \\
\hline Option A & Fiscal Law & Fiscal Law \\
\hline Option B & International Law & International Law \\
\hline
\end{tabular}

While approved in 2004, the new curriculum is not mandatory as yet as it will only be enforced beginning in the 2010 school year. The reason for such a lapse of time between its approval and its enforcement is mostly related to the discussion surrounding the duration of the course. For years, Brazilian legal studies have maintained an undergraduate requirement which would take five years to complete. The reforms have increased the amount of hours required for graduation from 2,700 (1972) to 3,300 (1994) and finally to 3,700 (2004) but have been unable to change the total year length of the course. Although there is no empirical evidence that such an amount of time would be necessary for the student to achieve its academic maturity, the Brazilian Bar and legal academia have been extremely resistant to change, with the Brazilian Bar even going to court in order to declare void a Ministry Ordinance reducing its length to three years. The court upheld the Bar opinion ${ }^{17}$ and in 2007, the Conselho Nacional de Educação (National Board of Education) stated that legal studies should be five years in length as a general rule and exceptions could only be made based on the quality and demands of pedagogical projects $^{18}$.

The debate over the length of legal studies is a perfect example of the lack of dialogue with the Bologna process. As one can imagine, the five year duration does not promote student mobility, lifelong learning or the establishment of a system based on two cycles, all of which are characteristics of the new educational environment proposed by the Bologna

\footnotetext{
17 See Superior Tribunal de Justiça, MS no 8,592-DF, Minister Franciulli Netto, available at http://www.jusbrasil.com.br/filedown/dev0/files/JUS/STJ/IT/MS_8592_DF_14.05.2003.pdf, last accessed 28 February 2009.

18 See Resolution CNE/CES no 02/2007, available at http://portal.mec.gov.br/cne/arquivos/pdf/2007/ rces002_07.pdf, last accessed 14 February 2009.
} 
process. Unlike other countries ${ }^{19}$, Brazilian legal scholars have mostly ignored the Bologna process and its consequences for legal education. The Brazilian Bar has not been very different in its approach, despite a tame attempt made by a former Bar President who suggested that two different cycles for legal education should be in the agenda ${ }^{20}$.

He suggested in April 2002 at the opening of the Brazilian Bar Association Sixth Seminar on Legal Education, that legal studies should last for seven years. The first cycle would last for five years but would not enable the graduate to practice as a lawyer, nor pursue any other legal careers. The professional exercise would only be possible after completion of the second cycle, lasting two years with its contents being defined under the supervision of Judicial Schools. In the VII Seminar on Legal Education held in May 2003, he mentioned once again a course of two cycles, with slight modifications in relation to his previous proposal, as the first cycle would be of three to four years and form a bachelor of laws, after which the student would be entitled to enter the second cycle, with a minimum duration of two years. It is important, however, to note that the Bar did not endorse his proposal, stating that the suggested division in two cycles lacked meditation and should be examined only as a possibility for the future. Unfortunately, the postponed debate never took place.

Another deferred debate relates to the integration of new technologies and challenges of an increasingly internationalized legal practice into Brazilian legal education. The Brazilian Bar has been extremely resistant to online education as it is perceived as a way to circumvent all the legal requirements of a face-to-face education. The Brazilian Bar refuses to think of it as a different form of legal education but insists on education through the same parameters of a classical classroom course. Thus, as it rejected the opening of a virtual legal course ${ }^{21}$, it also asked for a moratorium on all proposals of this kind ${ }^{22}$. Even so, the Brazilian Bar has not been able to stop the offer of Brazilian law online courses which operate abroad. These graduates face strong issues concerning the validity of their diplomas as they are not immediately recognized by Brazilian law ${ }^{23}$. Such online courses

\footnotetext{
${ }^{19}$ See Laurel S. Terry, The Bologna Process and its Implications for U.S. Legal Education, 57 JOURNAL OF LEGAL EDUCATION, 237 (2007), available at SSRN: http://ssrn.com/abstract=1086417, last accessed 10 February 2009. See also Andreas Bücker \& William A. Woodruff, The Bologna Process and German Legal Education: Developing Professional Competence through Clinical Experiences, 9 GERMAN LAW JournAL, 575 (2008).

${ }^{20}$ Rubens Approbato Machado, Exigências Práticas no Exercício Profissional e Limitações da Formação Jurídica, in OAB ENSINO JURÍDICO: FormA AÇÃo JURídICA E INSERÇão ProfisSIONAL, 17, 25 (Ordem dos Advogados do Brasil ed., 2003).

${ }^{21}$ See http://www.oab.org.br/oabeditora/users/revista/1235069367174218181901.pdf, last accessed 28 February 2009.

${ }^{22}$ See http://www.migalhas.com.br/mostra_noticia.aspx?cod=54606, last accessed 24 February 2009.

23 This is the case for the Brazilian Law International College (http://www.bliccollege.com/tikiindex.php?page $=$ Faculdade+de+Direito+a+Dist\%C3\%A2ncia, last accessed 27 February 2009) and the American World University (http://www.awu.edu/, last accessed 27 February 2009).
} 
illustrate the vast possibilities of a connected world that is also reshaping the legal profession.

Internationalization of legal practice has become a new reality as we move from a printbased industrial society to an IT-based information society. ${ }^{24}$ As new technologies are incorporated, judicial work is no longer what it used to be. ${ }^{25}$ Information circulates around the web at a speed that makes it very hard to keep track of. Legal practices are not immune to this movement and have increasingly incorporated information from other knowledge fields. As an international law market develops, the legal curriculum should be able to integrate foreign practices and cope with new challenges. However, this hardly happens. Neither the curriculum nor its clinical legal activities integrate such dimensions, although integrating foreign practices has been upheld by the latest reforms as an important dimension of Brazilian legal education.

Formally introduced by the Resolution CFE $3 / 1972$ as an autonomous part of the curriculum, clinical legal education did not develop as a pedagogical practice, but became in fact an alternative form of admission to the Brazilian Bar Association. Placed under the Bar supervision with a required minimum of 300 hours of practice, clinical aid offices allowed the student who went through this process with success to be automatically admitted to the Bar Association. Therefore, the Bar Exam was not required for those practicing (under supervision) in law school clinical aid offices. Needless to say that in a short period of time, the Bar Exam became irrelevant and the Brazilian Bar started to implement a thorough regulation for the clinical aid offices. This double regulation blurred the boundaries between academic and professional worlds; a problem that grew with the later reforms.

The 1994 curriculum reform established a compulsory installation in every law school of a Núcleo de Prática Jurídica (Legal Practice Center) aiming to contribute to a change in legal culture that would help clinical aid offices to go from a general practice of legal aid to a wider practice of giving legal advice. Basically, the Núcleo was supposed to break through the reproduction of an everyday jurisdictional life and change the adversarial logic present at Brazilian legal education. A few managed to do $\mathrm{so}^{26}$, but the majority was very shortly reduced to a reproduction of the past, i.e. a pasteurized student routine of collecting hours

\footnotetext{
${ }^{24}$ RICHARD SUSSKIND, THE END OF LAWYERS? RETHINKING THE NATURE OF LEGAL SERVICES (2008).

${ }^{25}$ Roberto Fragale Filho, The Use of ICT in the Brazilian Courts, paper to be presented to the $9^{\text {th }}$ European Conference on e-Government, London, 29-30 June 2009.

${ }^{26}$ See José Geraldo de Sousa Júnior, A Prática da Assessoria Jurídica na Faculdade de Direito da UnB, in A PRÁTICA JuRídicA NA UNB. ReCONHECER PARA EMANCIPAR, 21 (José Geraldo de Sousa Júnior, Alexandre Bernardino Costa and Mamede Said Maia Filho eds., 2007). See also José GERALdo de SousA JúnIOR (ed.), COLABORAdORES VolunTÁRIOS do NúCLEO de PRÁtICA JURÍDICA (2002).
} 
for graduation. ${ }^{27}$ Not even the reintroduction of the Bar Exam as a compulsory means to join the profession affected this reality. ${ }^{28}$ In fact, as it regained a mandatory status, the Bar Exam eliminated the idea of clinical aid offices as a shortcut to the profession, though it did not clarify the boundaries between legal academic and professional traineeship. The latest reform (2004) sought to emphasize the differences between the curricular and professional traineeship, but it is hard to anticipate what its outcome will be. The same unpredictability also applies to the required student final work as its format is no longer predefined while the 1994 curriculum established the monograph as a mandatory style. ${ }^{29}$

Uncertainty is a necessary characteristic of curricula reform that is on the verge of being implemented. The problem is that a curriculum modification does not necessarily change old teaching habits and little has been said (or done) about it. Pedagogical and curricular innovations are foreign to Brazilian law school classrooms. It is for instance almost impossible to find a single Brazilian law school that uses a problem based learning methodology. ${ }^{30}$ Brazilian law teachers seem still attached to the old conference style inherited from its Portuguese origins. Most of all, as the majority of Brazilian law teachers also practice another legal profession, the classroom becomes an extension of their professional offices where they recite and reproduce their most up-to-date everyday judicial experience. This teaching style has been under scrutiny as the legitimacy of teachers has been called into question in the wake of the higher education expansion and the implementation of an evaluative public system. As post-graduate degrees and scientific production become required for a teaching position, things may change, but first there is still a new curriculum to enforce and a growing corporation to control.

\footnotetext{
${ }^{27}$ The logic of collecting hours is also present at another curriculum requirement: the complementary activities. Every student is compelled to fulfill between $5 \%$ and $10 \%$ of the total amount of hours required for graduation by choosing to attend a seminar or participate in research, for instance, which are usually accepted as complementary activities.

28 Reintroduced by the Federal Act no 8,906/1994 (available at http://www.oab.org.br/arquivos/pdf/ LegislacaoOab/estatuto.pdf, last accessed 22 February 2009), the Bar Exam became mandatory for every law student two years later (article 84).

${ }^{29}$ Resistance to the final monograph came essentially from large schools that had a great difficulty in managing such a requirement for a large amount of students. It was extremely costly and time-consuming for a result that did not necessarily translate into evidence of quality.

${ }^{30}$ For a theoretical application of PBL to the Brazilian legal curriculum, see HoRÁcIo WANDERLEI RodRIGUES, PENSANDO o Ensino do Direito no Século XXI: Diretrizes Curriculares, Projeto Pedagógico e Outras Questões Pertinentes 152 (2005).
} 


\section{Control over the profession}

Created by law in 1930, the Brazilian Bar Association is a federal public service that has over the years played a double role as a simultaneous gatekeeper for the national institutions and the profession. ${ }^{31}$ In the first role, the law establishes the defense of the Constitution, Rule of Law, human rights and social justice as purposes of the Bar. It is also legally responsible for a permanent call for a proper application of laws, a swift administration of justice and an improvement of cultural and legal institutions. In its second role, it promotes, with exclusivity, the representation, defense, selection and discipline of lawyers throughout the country. ${ }^{32}$ Throughout its history, the importance accorded to one or another function has oscillated accordingly to the circumstances. Undoubtedly the resistance to the military government when it ruptured the legal order has allowed the corporation to increase its political capital and become sort of an "official" voice for the civil society during the redemocratization period. This renewed and amplified legitimacy allowed an expansion of the Bar's professional control through the incorporation of a new legal competency, to "collaborate for the improvement of legal education, and give its opinion on the applications submitted to the competent bodies for the creation, recognition or accreditation of these courses". ${ }^{33}$

The Brazilian Bar quickly approved the general criteria $^{34}$ for the creation and accreditation of a course. Among them, the criteria of social need which should be evidenced through studies relating socio-economic, demographic, level of services and productions, existence of qualified personnel, and other aspects of the educational region of influence for the proposed new school. Although this approach would be abandoned by the Ministry of Education as a public policy of higher education, as discussed earlier, the Brazilian Bar remained nonetheless attached to such criteria. While the Ministry offered a new regulation for the expansion process, the Bar issued its new regulation ${ }^{35}$ in which a set of elements was demanded in order to establish the existence of social need. The applications should provide for the Municipality, or the equivalent area of a radius not superior than 50 kilometers from the future law school headquarters, specific data

\footnotetext{
${ }^{31}$ See Maria da Glória Bonelli, Profissionalismo e Política no Mundo do DiReito 56 (2002).

${ }^{32}$ See Federal Act no 8,906/1994 (article 44, I and II).

${ }^{33}$ See Federal Act no 8,906/1994 (article 54, XV). The Brazilian Bar opinion, although required by law, does not produce the same results as the American Bar Association (ABA) accreditation process which is not exempt of criticism. See Mathew D. Staver and Anita L. Staver, Lifting the Veil: an Exposé on the American Bar Association's Arbitrary and Capricious Accreditation Process, 49 THE WAYNE LAW REVIEW 1 (2003), available at: http://digitalcommons.liberty.edu/cgi/viewcontent.cgi?article=1005\&context=lusol_fac_pubs, last accessed 27 February 2009.

${ }^{34}$ See Instrução Normativa (Normative Instruction) OAB n 5/1995.

${ }^{35}$ See Instrução Normativa (Normative Instruction) OAB no $1 / 1997$.
} 
indicating: (a) general population, which can not be less than 100,000 inhabitants as to establish a ratio of an initial maximum number of 100 vacancies per year to 100,000 inhabitants; (b) number of high schools and enrolled students; (c) number of higher education institutions, graduate and undergraduate courses and places offered; (d) the average candidate/vacancy in the latest admission exams for any existing legal course; (e) composition of the systems of justice and security; (f) number of lawyers entered in the local section of the Bar; (g) legal offices or entities capable to absorb trainees; (h) legal bookstores and libraries open to public consultation; (i) curricula vitae of future teachers and their statements of commitment to the course.

The vague concept of social need ${ }^{36}$ subsequently gained a clearer frame as it is quite evident that such data would be used to establish some kind of empirical relation between the local population and the allegedly corresponding legal market both within the applicant's area of installation. Although an "ideal" ratio was never established, the Brazilian Bar always sustained that it has never been a matter of safeguarding the legal market from newcomers but just a necessary measure to preserve the quality of Brazilian legal education. As the educational public policy and the professional discourse grew apart, it became necessary for the Bar to reinvent quality measurement. This came from the reintroduction of the mandatory Bar Exam.

Indeed, the high percentage of failure at the Bar Exam was used by the Brazilian Bar as a clamorous evidence of the poor quality of legal education. After each one of the three yearly occasions (April, August and December) in which the Bar Exam was offered, as the results were made public, a general wave of criticism arouse to condemn the poor quality of Brazilian legal education, the fragile character of the higher education expansion, and even the merchandization of education. Bar Exam results were used not only to criticize legal education but also to separate the good schools from the bad ones. This was done through the concession of $O A B$ Recomenda, a Bar seal of approval given to schools whose excellence was demonstrated by the Bar Exam results as well as the results obtained at the Exame Nacional de Cursos (National Exam of Courses) ${ }^{37}$. The seal, which has been strongly criticized for its methodology ${ }^{38}$ has had three iterations in which its results honored

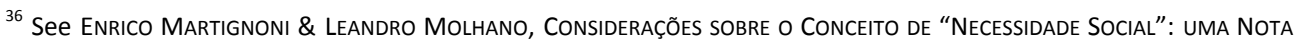
TÉCNICA (2005), available at: http://www.databrasil.org.br/Databrasil/..\%5Cpdf_docs\%5CDoctrab46.pdf, last accessed 23 February 2009.

${ }^{37}$ Replaced in 2004 by the Exame Nacional de Desempenho de Estudantes (National Exam of Students' Performance), the Exame Nacional de Cursos was a universally applied exam to graduates in order to evaluate the quality of Brazilian higher education. Its results were expressed through five grades from $A$ to $E$ and were quickly adopted by the press to establish some sort of school ranking. For more information, see http://www.inep.gov.br/superior/provao/default.asp, last accessed 17 February 2009.

38 See Édson nunes, andré Magalhães nogueira \& Leandro Molhano Ribeiro, futuros possíveis, Passados INDESEJÁveIS: SELo da OAB, PRovÃo e AVALIAÇão do ENSINo SUPERIOR 75 (2001).
} 
respectively $52^{39}, 60^{40}$ and $87^{41}$ legal courses, although every iteration has used a diverse methodology. The impending forth iteration will be no different as its two major components have undergone through changes: on one hand, the Bar Exam is no longer conceived and offered on a State basis as it has been almost nationally unified ${ }^{42}$ (which will allow a comparative exercise on a more secure and consistent basis) and on other hand, the Exame Nacional de Cursos has been replaced by the Exame Nacional de Desempenho de Estudantes, where results are expressed through two different grades (one expressing the average for each and every school group of students in itself and other expressing a comparative result for all students taking part in the exam).

Thus, the Bar Exam became an extremely important tool for the Brazilian Bar to regain its lost preeminence. As the number of students unable to exercise a legal profession grew due to the Bar Exam failure rates, the Bar discourse gained force and the Bar was once again able to interfere within the higher education public policy. Therefore, the environment provided for at the 180 years celebration of legal education in Brazil could not have been better for the consolidation of a major change in the dialogue between the Bar and the Ministry of Education. Nevertheless, all of this transformation translates into a lot of graduates eager to practice a legal profession. This has produced a major change in every legal corporation. The still unaccounted for major change produced by the expansion is that legal professions are no longer reserved for a few, but have become mass professions. For instance, the legal corporation with its 600,000 members can hardly remain as a small professional community that enhances its legitimacy from the daily contact among its members. A reinvention of the corporation as well as of legal studies has to be on the agenda.

\section{Summary}

Since 1994, Brazilian legal education has been engaged in a long and inconclusive process of curriculum reform in which the Ordem dos Advogados do Brasil (Brazilian Bar Association) has been one of its greatest players. The transformations undertaken in legal education in the last two decades, were buoyed by (a) the redemocratization of the country, completed in 1988 with the promulgation of the new Constitution, (b) the expansion of higher education, which resulted in a amount of more than half a million law

\footnotetext{
${ }^{39}$ Ordem dos Advogados do BRASIL, OAB ReComenda: UM Retrato dos CuRSOS Jurídicos (2001).

${ }^{40}$ Ordem dos Advogados do Brasil, oAB Recomenda 2003: EM DefESA do ENSINO Jurídico (2003).

${ }^{41}$ Ordem dos Advogados do Brasil, OAB Recomenda 2007: Por um Ensino Jurídico de Qualidade (2007), available at http://www.oab.org.br/arquivos/pdf/oabRecomenda/OABRecomenda1.pdf, last accessed 14 February 2009.

${ }^{42}$ Minas Gerais is currently the only recalcitrant State. See http://www.oab.org.br/noticia.asp?id=15946, last accessed 17 February 2009.
} 
students, and (c) the protection of interests of the lawyers' corporation. While the expansion made the Brazilian Bar go from a situation where it had little control, to a situation where it had no control at all, the curriculum reform has blurred the boundaries between legal academia and professional practice. The Brazilian Bar, legitimated by a series of studies denouncing the anachronism of Brazilian legal education, especially after the introduction of the 1988 Constitution, played an important role in every curriculum change introduced over the last two decades. The latest reform, which will only be enforced in the 2010 school year, adds a little more to the uncertainty of their effectiveness as one perceives a lack of dialogue with the Bologna process and a poor integration of the challenges of an increasingly internationalized legal practice. Although the Brazilian Bar has been able to regain its status through a renewed mandatory Bar Exam, it has not been able to depart from old teaching habits of law professors. Briefly, Brazilian legal education is facing a broad challenge that goes beyond the definition of its curriculum structure. Rethinking the foundations of its accessibility and the importance of its social impact is undoubtedly a necessity to adequately speculate about the future of Brazilian legal education. 